\title{
FACTORS AFFECTING PROCUREMENT PERFORMANCE IN THE INDUSTRIES AT BATAM
}

\author{
Immanuel Zai \\ Universitas Internasional Batam, Batam, Indonesia \\ Corresponding author: immanuel.zai@uib.edu
}

\begin{abstract}
The objective of this study is to examine factors affecting procurement performance in the industries at Batam. Information and communication technology, staff competence, and ethics are the most factors that affect procurement performance. This research model was tested using a non-purposing sample with survey data on 201 respondents directly related to procurement in industries at Batam. The results of this study support the proposed research model that information and communication technology, staff competence, and ethics have a significant positive effect on procurement performance in the chosen industries at Batam. The studies also found that the application of information and communication technology in procurement had the most excellent and most positive significant effect on improving procurement performance.
\end{abstract}

Keywords: Procurement performance, information and communication technology, staff competence, ethics, supply chain, supply management.

\section{Introduction}

Procurement is a business management function to ensure the identification, sourcing, access, and management of external resources needed by the organization (cips.org), the existence of procurement serves to explore market opportunities for suppliers and services and implement resource strategies providing the best supply and services for organizations and stakeholders. The better the procurement performance will reduce costs and increase company profits. In the past decade, 36 studies was researching on procurement performance and has been investigated by Vaidyanathan and Devaraj (2007), Quesada, Gonzalez, Mueller and Mueller (2010), Devaraj, Vaidyanathan, Mishra (2012), Vaidyanathan, Devaraj, D'Arcy (2012), Mishra, Devaraj, Vaidyanathan (2013), Kiage (2013), Amemba, Nyaboke, Osoro and Mburu (2013), Mady, Mady and Mady (2014), Willy and Njeru (2014), Karanu and Njeru (2014), Kemuntho and Ngugi (2014), Kioko and Were (2014), Nyangau, Mburu and Ogollah (2014), Loice (2015), Sumpikova, Namec, Orviska and Grega (2015), Mukopi and Iravo (2015), Gommans and Kari (2015), Rotich, Bernard and Warugu (2015), Lam and Gale (2015), Wanyonyi and Muturi (2015), Rotich and Okello (2015), Osir (2016), Patrocco, Luzzini and stefano (2016), Macharia and Mwangangi (2016), Krop and Iravo (2016), Hamza, Gerbi and Ali (2016), Philly, Were and Nkrinal (2017), Mwita and Mwaighacho (2017), Oromo and Mwangangi (2017), Numakasa (2017), Kubochi and Moronge (2017), Mugwe and Ngugi (2017), Irungu and Were (2017), Ogol and Moronge (2017). Mady et al., (2014).

The notion of procurement performance study has become a trend in several public and private sector researchers in developed and developing countries. This study aims to find factors affecting procurement performance in Indonesia, especially Batam, in the private sector.

\section{Theoretical and Hypothesis Development}

From the meta-analysis results, three factors often appear to affect procurement performance, and the categories are described in more detail as follows.

In the summary of previous studies, information technology and technology is the variable that most often appears as an independent variable affecting procurement performance. There are 12 studies in the last decade as an independent variable affecting procurement performance, including Vaidyanathan and Devaraj (2007) in the aerospace, automotive, electronics, and consumer goods industries are the researcher to examine that information and communication technology affects the procurement performance, in his research, the quality of workflow information (online information, purchasing procedures) has a significant impact on the fulfillment of the logistics quality flow affecting the procurement performance. Quesada et al. (2010) in the manufacturing industry shows in its framework that the application of information and communication technology has a positive and significant impact on procurement performance. The same results were also found by Amemba et al. (2013), research that the application of information and communication technology affects the procurement performance in the public sector; investing in information and communication technology, especially in e-procurement, has become government efforts to become a modern government, these efforts can reduce opportunities for corruption, increase accountability and process transparency. Furthermore, in the public sector, Karanu and Njeru (2014) revealed that the application of information technology (online auction advertisements, auction processes, and computer selection) affects procurement performance positively; in this study, the procurement performance is 
transparent, effective, efficient, and productivity. Wanyonyi and Muturi (2015) also found the same result in public sector research, and information technology affects procurement performance positively. Likewise with Mugwe and Ngugi (2017) in their research in the public sector found the IFMS system or information security and bribery detection, online auctions, automatic planning, and supplier involvement automatically affect procurement performance positively and significantly.

Furthermore, Rotich et al., (2015), in their research on e-tendering, and Rotich and Okello (2015) in their research on Enterprise Resource Planning in the public sector found that information and communication technology affect and improve procurement performance. The same thing was also found by Osir (2016) in the public sector in the education sector that information technology and technology in the form of eprocurement (e-tendering, e-awarding, e-invoicing) effect on procurement performance significantly positive. Furthermore, Mwita and Mwaighacho (2017) explain in research at the port authority of the public sector that information and communication technology in the form of e-procurement affects procurement performance significantly positively. Irungu and Were's (2017) research on port authorities in the public sector, Enterprise resource planning, an integral part of information and communication technology, positively affects procurement performance. Similar to Kemunto and Ngugi (2014), in their research in the pharmaceutical industry in the private sector that technology affects procurement performance significantly positively. Meanwhile, Kioko and Were (2014) examined at the Ministry of Land in the public sector that information and communication technology have no significant impact on procurement performance.

Staff competence is one-factor affecting procurement performance. This notion is in line with previous studies found by Kiage (2013) in his research in the energy industry in the public sector that staff competence has a significant positive effect on procurement performance. Mishra et al. (2013), in the same year in their research on the private sector in the machinery and computer equipment industry, electronic equipment, transportation equipment, instruments, health, and clocks, found that the competency of the integration of goods and services procurement (knowledge of internal processes, knowledge of relationships external) as follows, that the higher the competency of the procurement integration, the higher the competence of the procurement digital which has a positive effect on the procurement performance process. Furthermore, Karanu and Njeru (2014), in their research in the milk processing industry in the private sector, found that staff competencies consisting of worker satisfaction, work experience, worker ability, education level, professional qualifications significantly affect the procurement performance. Wanyonyi and Muturi (2015) also found the same thing in their research on technical training in the public sector that staff competence has a significant positive effect on procurement performance.

Furthermore, Macharia and Mwangangi (2016) found that staff competence has a significant positive effect on procurement performance in their research in the telecommunications industry in the public sector. Hamza et al. (2016), in their research in the private sector in the textile industry, also found that staff competence and human resource placement had a positive effect on procurement performance. Furthermore, Mwita and Mwaighacho (2017) found that staff competency has a significant and positive effect on procurement performance in a study of port authorities in the public sector. Meanwhile, Kioko and Were (2014), in their research at the Ministry of Land in the public sector, explained that staff competence does not significantly affect procurement performance or hurt procurement performance.

Ethics was examined by several researchers affecting procurement performance. It is in line with previous studies that Amemba et al. (2013) found in their research that the ethics of procurement staff affect procurement performance significantly and positively in the public sector. Furthermore, Loice (2015), in his research in the retail industry of the private sector, found that although his hypothesis states that trust does not affect procurement performance, the results of the study state that trust, which part of ethics affects procurement performance significantly. The same thing was found by Kioko and Was (2014). Their research at the Ministry of Land in the public sector found that culture in institutions (culture and behavior, management, rules and policies, ethics) positively affect the procurement function, Orgol, and Moronge. (2017) in the public health sector, the research found that ethics affects procurement performance. Meanwhile, Wanyonyi and Muturi (2015), in research in the public sector, found that staff work ethics harmed procurement performance. The same thing was also observed by Philly et al. (2017) that conflicts of interest (personal gain, nepotism, outside influences), which are categorized as ethics, harm procurement performance.

In supporting the research model described above, it can be modeled in the form of a hypothesis as below. H1. Information Communication and Technology have a positive effect on procurement performance.

H2. Staff competency has a positive effect on procurement performance.

H3. Ethics has a positive effect on procurement performance.

\section{Research Method}

This study targets 250 offshore fabrication companies, shipbuilding, construction, manufacturing, hotels, retail, trading, and transportation services in Batam - Indonesia. The research target is 300 staff, managers, people who are directly involved in procurement and returned data 201 respondents. The questionnaire was collected using a survey method with a Likert scale of 1-5 and a gradation of statements strongly disagree to agree strongly. Research instruments for information and communication technology contain a summary 
statement of integrated computer and communication technology used to improve the procurement performance consisting of 10 statements Likert scale 1-5, staff competency research instruments with a summary statement of experience and expertise in procurement which consists of 6 statements Likert scale 15 and research instruments for ethics with a summary of positive and negative action statements from external and internal factors that affect the procurement process consisting of 9 statements, Likert scale 1-5 obtained from Kioko and Were (2014). While the research instrument for the procurement performance with a summary statement of effectiveness, value for money, and customer satisfaction in the procurement process consisting of 7 statements with a Likert scale of 1-5 obtained from Philly et al. (2017).

\section{Result and Discussion}

In this study, the results of hypothesis testing using multiple regressions are described as follows:

Table 1. F test

\begin{tabular}{cccc}
\hline Variable & F & Sig. & Conclusion \\
\hline Procurement Performance & 80,698 & 0,000 & Significant \\
\hline
\end{tabular}

The results of the F test in Table 2 obtained a probability level of 0.000 which is $<0.05$, which means that the research model can be used to predict the dependent variable (the procurement performance).

Table 2. t-Test procurement performance

\begin{tabular}{llcrll}
\hline Variable & $\begin{array}{c}\text { Understand } \\
\text { Coeff }(\mathrm{B})\end{array}$ & $\begin{array}{c}\text { Stand. Coeff } \\
\text { Beta }\end{array}$ & $\mathrm{t}$ & Sig. & Conclusion \\
\hline (Constant) & 6,478 & & 2,481 & 0,005 & \\
\hline Ethics & 0,204 & 0,182 & 3,144 & 0,002 & Significant \\
\hline Staff competence & 0,213 & 0,178 & 3,105 & 0,002 & Significant \\
\hline ICT & 0,442 & 0,547 & 10,258 & 0,000 & Significant \\
\hline
\end{tabular}

The significance level of information and communication technology on procurement performance is less than $0.05(0.000)$ with $\mathrm{t}$ table $<\mathrm{t}$ count $(1.97196<10.258)$. Furthermore, where each increase is 1 unit of technology information and communication will increase the procurement performance value by 0.442 , it can be concluded that the information and communication technology affect procurement performance significantly positively. It is consistent with research conducted by Vaidyanathan and Devaraj (2007), Quesada et al. (2010), Amemba et al. (2013), Karanu and Njeru (2014), Wanyonyi and Muturi (2015), Mugwe and Ngugi (2017), Rotich et al., (2015), Rotich and Okello (2015), Osir (2016), Mwita and Mwaighacho (2017), Irungu and Were (2017), Kemunto and Ngugi (2014). However, this is not consistent with the research of Kioko and Was (2014).

The significance level of staff competence on procurement performance is less than $0.05(0.002)$ with $t$ table < t count $(1.97196<3.105)$. Furthermore, where each increase of 1 staff competency unit will increase procurement performance value by 0.213 , it can be concluded that staff competence affects procurement performance significantly and positively. The results of this study are consistent with research conducted by Kiage (2013), Mishra et al. (2013), Karanu and Njeru (2014), Wanyonyi and Muturi (2015), Macharia and Mwangangi (2016), Hamzah et al. ( 2016), Mwita and Mwaighacho (2017), Ogol and Moronge (2017). However, this is not consistent with the research of Kioko and Was (2014).

The significance level of ethics on procurement performance is less than $0.05(0.002)$ with $t$ table $<t$ count $(1.97196<3.144)$. Moreover, where every increase of 1 ethical unit will increase procurement performance value of 0.204 , it can be concluded that there is a significant positive effect of ethics on procurement performance. This study is consistent with research conducted by Amemba et al. (2013), Loice (2015), Kioko and Were (2014), Orgol Moronge (2017). However, this is not consistent with Wanyonyi and Muturi's (2015) research and Philly et al.'s (2017).

If the standardized coefficient value is closer to 1 , the effect of the independent factor is more significant on the dependent (Cremer, 2011).

Table 3. R test and Adjusted $\mathrm{R}^{2}$

\begin{tabular}{ccc}
\hline Variable & $\mathrm{R}$ & Adjusted $\mathrm{R}$ Square \\
\hline Procurement performance & 0,743 & 0,545 \\
\hline
\end{tabular}

The adjusted $\mathrm{R}$ square value of 0.545 means that the independent variables can explain the dependent variable by $54.5 \%$. Other variables influence the remaining $45.5 \%$. 


\section{Conclusion}

In this study, empirical evidence found that industries such as offshore fabrication, shipbuilding, construction, manufacturing, hospitality, retail, trading, and transportation services companies in Batam show that information, communication, technology, staff competence, and ethics are significant positive on procurement performance. Several solutions to this research problem can be resolved by improving the most significance start from information and communication technology, ethics, and staff competence.

\section{Reference}

APICS (2016). Certified Supply Chain Profesional $4^{\text {th }}$ ed.

Amemba, C. S., Nyaboke, G. P., Osoro, A., \& Mburu, N. (2015). Challenges Affecting Public Procurement Performance Process in Kenya. European Journal of Business and ManagementOnline), 7, 271-280.

Devaraj, S., Vaidyanathan, G., \& Mishra, A. N. (2012). Effect of purchase volume flexibility and purchase mix flexibility on e-procurement performance: An analysis of two perspectives. Journal of Operations Management, 30(7-8), 509-520. https://doi.org/10.1016/j.jom.2012.08.001

Gommans, H. P., \& Kari, J. M. (2015). The Influence of Supply Chain Management Practices on the Procurement Performance of Horticulture Companies (A Case Study of Homegrown Horticulture company, Naivasha). International journal of scientific and research publications, 5(11), 555-569. http://www.ijsrp.org/research-paper-1115/ijsrp-p4783.pdf

Hamza, S. B., Gerbi, A., \& Ali, S. H. (2016). Factors Affecting Procurement Performance in the Case of Awassa Textile Share Company. Global Journal of Management And Business Research, 16(3), 31-43. https://www.journalofbusiness.org/index.php/GJMBR/article/view/2085

Irungu, M. N. \& Were, S. (2017). Effect of strategic information system on procurement performance in parastatals in Kenya: A case of Kenya ports authority (KPA). International journal of innovations, Business, and management, 11 (11).

Karanu, S. M., \& Njeru, A. (2014). Factors Affecting Procurement Performance in the Milk Processing Firms In Kiambu County. International Journal of Science and Research, 3(1), 104-109.

Kebaso, I. (2014). Effects of Outsourcing Strategy on Procurement Performance Among Universities in Kenya. International Journal of economics, commerce, and management, II(11), 1-40.

Kemunto, D. \& Ngugi K. (2014). Influence of strategic buyer-supplier alliance on procurement performance in private manufacturing organizations a case of Glaxo Smithkline. European journal of business management, 2 (1), 336-341.

Kiage, J. O. (2013). Factors Affecting Procurement Performance: A Case of Ministry of Energy. International Journal of Business and Commerce, 3(1), 54-70.

Kioko, N. J., \& Were, S. (2014). Factors Affecting Efficiency of the Procurement Function at the Public Institutions in Kenya (A Case of Supplies Branch in Nairobi). International Journal of Business \& Law Research, 2(June), 1-14. https://seahipaj.org/journals-ci/june-2014/IJBLR/full/IJBLR-J-1-2014.pdf

Krop, E. (2016). Effects of Supplier Selection on Performance of Procurement Function in Public Sector : a Case of West Pokot County Government. International academic journal of procurement and supply chain management, 2(2), 51-73. http://www.iajournals.org/articles/iajpscm_v2_i2_51_73.pdf

Kubochi D. B. \& Moronge M.(2017). Influence of performance contracting on procurement performance among county governments in Kenya. International journal of supply chain and logistic, 1 (3), 68-96. https://doi.org/10.47941/ijscl.209

Lam, T. Y., \& Gale, K. . (2018). A Procurement Performance Model for Construction Frameworks. Journal of Engineering, Project, and Production Management, 5(2), 60-70. http://doi.org/10.32738/JEPPM.201507.0002

Loice, K. (2015). Effect of Buyer-Supplier Relationships on Procurement Performance. European Scientific Journal, 1(December), 54-70.

Mishra, A. N., Devaraj, S., \& Vaidyanathan, G. (2013). Capability hierarchy in electronic procurement and procurement process performance: An empirical analysis. Journal of Operations Management, 31(6), 376-390. https://doi.org/10.1016/j.jom.2013.07.011

Mito Mukopi, C., \& Mike Iravo, A. (2014). An Analysis of the Effects of Inventory Management on the Performance of the Procurement Function of Sugar Manufacturing Companies in the Western Kenya Sugar Belt. International Journal of Scientific and Research Publications, 5(1). http://www.ijsrp.org/research-paper-0515/ijsrp-p41117.pdf

Mugwe, M. G. \& Ngugi, L. (2017). Integrated financial management information system and its influence on public procurement performance in Kiambu county government, Kenya. International journal of social science and information technology, 3 (9). http://ir-library.ku.ac.ke/handle/123456789/19233

Mwita, P., Mwaighacho, S., \& Azanlerigu, J. A. (2017). Effect of E-Procurement on Procurement Performance in Kenya Ports Authority. Imperial journal of interdisciplinary research, (5), 624-636. http://www.onlinejournal.in/IJIRV3I5/094.pdf

Namukasa, J. (2017). Records management and procurement performance: A case of NAADS program in the central region of Uganda. Records Management Journal, 27(3), 256-274. http://doi.org/10.1108/RMJ-04$\underline{2016-0011}$ 
Ogol, C. O., \& Moronge, M. (2017). Effects of ethical issues on procurement performance in public hospitals in Kenya: a case of Kenyatta national referral hospital. The strategic journal of business \& change management, 4(3) 49, 787-805. https://strategicjournals.com/index.php/journal/article/view/541

Oromo, F. A. O., \& Mwangangi, P. (2017). Effect of Supplier Development on Procurement Performance in Public Sector in Kenya: A Case of Kenya Electricity Generating Company Limited. International Journal of Supply Chain Management, 2(3), 42-59.

Osir, E. O., (2016). Role of E-Procurement Adoption on Procurement Performance in State Corporations in Kenya : a Case of Kenya Utalii College. International academic journal of procurement and supply chain management, 2(Part 1),66-100. https://www.iajournals.org/articles/iajpscm_v2_i1_66_100.pdf

Patrucco, A. S., Luzzini, D., \& Ronchi, S. (2016). Evaluating the Effectiveness of Public Procurement Performance Management Systems in Local Governments. Local Government Studies, 42(5), 739-761. https://doi.org/10.1080/03003930.2016.1181059

Philly, R. K., Were, S., \& Nkirina, S. P. (2017). Effects of conflict of interest on procurement performance in referral hospitals in Kenya: A case of Kenyatta national hospital (KNH) Nairobi, Kenya. International journal of supply chain management, 2 (2) 2, $22-41$.

https://www.iprjb.org/journals/index.php/IJSCM/article/view/486

Quesada, G., Gonzales, M.E., Mueller, J., \& Mueller, R.(2016). Impact of e-procurement on procurement practices and performance. An international journal, 17 (14), 516-538. http://doi.org/10.1108/14635771011060576

Rotich, G. K. \& Okello B. (2015). Analysis of Use of E-Procurement on Performance of the Procurement Functions of County Governments in Kenya. International journal of economics, commerce, and management, III(6), 1381-1398.

Rotich, G. (2015). Relationship Between E-Tendering and Procurement Performance Among County Governments in Kenya. Science Innovation, 3(5), 46. http://doi.org/10.11648/j.si.20150305.11

Sugiyono. (2017). Metode Penelitian Kuantitatif, Kualitatif, dan R\&D. Bandung : Alfabeta, CV.

Sumpikova, M., Nemec, J., Orviska, M., \& Grega, M. (2015). Selected Factors Determining the Performance of the Czech Public Procurement System. CBU International Conference Proceedings, 3, 242. http://doi.org/10.12955/cbup.v3.608

Tawfik, M., Mady, T. T., \& Mady, S. T. (2014). Procurement performance and manufacturer-supplier relationships: A multivariate analysis in Kuwaiti manufacturing companies. Journal of Business and Industrial Marketing, 29(5), 417-426. https://doi.org/10.1108/JBIM-01-2012-0005

Vaidyanathan, G., \& Devaraj, S. (2008). The role of quality in e-procurement performance: An empirical analysis. Journal of Operations Management, 26(3), 407-425. https://doi.org/10.1016/j.jom.2007.08.004

Vaidyanathan, G., Devaraj, S., \& Arcy, J.D'. Does security impact e-procurement performance? Testing a model of direct and moderate effects. A journal of the decision science institute, 43 (3) 437-459. http://doi.org/10.1111/j.1540-5915.2012.00354.x

Wanyonyi, S., \& Muturi, W. (2015). Factors affecting the performance of procurement function among public technical training institutions in Kisumu County, Kenya. International Journal of Economics, Commerce and Management, 3(5), 1-35. http://dx.doi.org/10.6007/IJARBSS/v5-i4/1572

Willy, Kibet \& Njeru, Agnes (2014). Effect of procurement planning on procurement performance: A case study of the agriculture development corporation, Nairobi. International Journal of Business and Commerce, 3 (12), 58-68. https://www.ijbcnet.com/3-12/IJBC-14-31109.pdf

Wachera Macharia, S., \& Mwangangi, P. (2016). Influence Of Total Quality Management On Procurement Performance In Telecommunication Industry In Kenya: A Case Of Safaricom Company Limited. International Journal of Business \& Law Research, 4(4), 12-33. https://seahipaj.org/journals-ci/dec2016/IJBLR/full/IJBLR-D-2-2016.pdf 